\title{
Kültürel Turistlerin Seyahat Tercihleri ve Yiyecek-İçecek Beklentileri: Safranbolu Örneği
}

Yrd. Doç. Dr. Nurettin AYAZ, Karabük Üniversitesi, Safranbolu Turizm Fakültesi, eposta: nurettinayaz@karabuk.edu.tr

Sibel YALI, Karabük Üniversitesi, Sosyal Bilimler Enstitüsü, e-posta: sibel su 9999@hotmail.com

Öz

Turizm temalı seyahatlerde yiyecek-içeceklerin müşteri ile buluşturulması sonucunda ortaya çıkan deneyimlerin öğrenilmesi, müşterinin memnuniyetini ve yeniden ziyaretini sağlama adına önemli bir gerekliliktir. Bununla birlikte müşterilerin farklı kişilik özellikleri ve sürekli değişen talepleri nedeniyle turizme yönelik hizmetlerde en az memnuniyet sergilenen hizmet alanlarından bir tanesini de yiyecek ve içecek hizmetleri oluşturmaktadır. $\mathrm{Bu}$ araştırmada, kültür turizmi temalı ziyaretlere katılan yerli turistlerin seyahat tercihleri ve yiyecek-içecek beklentileri arasındaki ilişki test edilmektedir. Bu doğrultuda UNESCO tarafından Dünya Mirası içerisinde gösterilen ve kültür turizmi için önemli bir varış noktası olan Safranbolu ilçesini ziyaret eden yerli turistlerden elde edilen veriler kapsaminda seyahat tercihi ve yiyecekiçecek beklentisi ilişkisi test edilmiştir. Bu amaç doğrultusunda 391 yerli turiste, Şubat-Haziran 2016 döneminde veri toplamak amaciyla anket uygulanmıştır. Anket verileri kapsamında yerli turistlerin yiyecek-içecek beklentileri; hijyen, hizmet sunumu, yemek ve salon atmosferi öncelik sirasinda belirlenmiştir. Ayrıca yerli turistlerin seyahat tercihleri ile yiyecek-içecek beklentisi ilişkisine yönelik gerçekleştirilen Korelasyon Analizi kapsamında orta düzeyde $(\mathrm{r}=0,566 ; \mathrm{p}=0,000)$ olmak üzere pozitif yönlü anlamlı bir ilişki tespit edilmiştir.

Anahtar Kelimeler: Kültürel turist, Seyahat tercihi, Yiyecek-içecek beklentisi, Safranbolu.

\section{Önerilen Atıf:}

Ayaz, N. ve Yalı, S (2017). Kültürel Turistlerin Seyahat Tercihleri ve Yiyecek-İçecek Beklentileri: Safranbolu Örneği, Türk Turizm Araştırmaları Dergisi, Cilt.1, Sayı.1, ss. 43-61. 


\title{
Travel Preferences of the Cultural Tourists and Their Expectations about Food and Beverage Services: The Case of Safranbolu
}

\author{
Assistant Prof. Dr. Nurettin AYAZ, Karabük University, Safranbolu Faculty of Tourism e- \\ mail: nurettinayaz@karabuk.edu.tr
}

Sibel YALI, Karabük University, e-mail: sibel su 9999@hotmail.com

\begin{abstract}
Learning the experiences, which result from the meeting of the customers with the food and beverage related with tourism theme, is an important factor that shapes customer satisfaction levels and their revisit. Additionally, due to the personal traits of the customers and their different demands, food and beverage service has been one of the services with the lowest customer satisfaction. This study tests the relationship between the travel preferences of the domestic tourists that engage in cultural tourism and their expectations about food and beverage. Within this context, we analyzed data obtained from the domestic visitors, which visited the district of Safranbolu, a city that is a piece of the world heritage by the UNESCO and an important cultural tourism destination in Turkey. We obtained data by using survey on 391 tourists between February and June 2016. The study found that hygiene, service presentation, quality of food, and the atmosphere of the saloon were determined as the expectations of the domestic tourists about the food and beverage services, respectively. Furthermore, correlation analysis on the relationship between the traveling preferences of the domestic tourists and their expectations on the food and beverage preferences found medium level $(\mathrm{r}=0,566 ; \mathrm{p}=0,000)$ and positive meaningful relationship.
\end{abstract}

Key Words: Cultural tourist, Travel preference, Expectations about food and beverage service, Safranbolu.

\section{Suggested Ctitation:}

Ayaz, N. and Yalı, S (2017). Travel Preferences of the Cultural Tourists and Their Expectations about Food and Beverage Services: The Case of Safranbolu, Journal of Turkish Tourism Research, Vol.1, Issue.1, pp. 43-61.

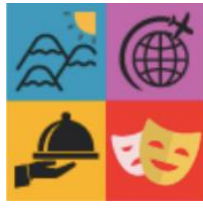

Journal of Turkish Tourism Research Vol. 1, Issue.1, 2017

pp. 43-61. 


\section{Gíriş}

Turistin bakış açısıyla turizm; bir rahatlama ve eğlence deneyimidir. Bu deneyim sürecinde turistler, farklı ruhsal ve fiziksel memnuniyetler peşinde koşarlar, destinasyon ve aktivite seçimlerini bu memnuniyetleri çerçevesinde belirlerler (Ayaz, 2012). Yeme ve içme, fizyolojik ihtiyaçlarını gidermenin yanısıra yeni lezzetler tatmak, arkadaşlarla birlikte zaman geçirmek, tükettiği yiyeceklerden ve bulunduğu yerden zevk almak, yeni arkadaşlıklar kurmak, boş zamanlarını değerlendirmek vb. amaçlarla öne çıkan bir turist deneyimidir. $\mathrm{Bu}$ anlamda yiyecek ve içecekler; fizyolojik, psiko-duyusal ve sosyal çevrenin bir parçası olarak görülebilir (Avcıkurt vd., 2007; Bekar vd., 2011; Bucak ve Ateş, 2014; Bekar ve Kılıç, 2014).

Seyahate çıkan turistler için yemek yeme; bir turizm davranışı ve yiyecek ve içecekler birer çekicilik unsurudur. Bu nedenle yiyecek ve içecek hizmetlerinde kalite adına müşteri beklentilerinin önceden öğrenilmesi öne çıkarılmalıdır. Hijyen başta olmak üzere yiyecek ve içecek çeşitliği, sunum ve tutarlı hizmet sunumu önemli unsurlardır. Sürekli değişen ve gelişen tüketici istekleri doğrultusunda bu beklentilerin karşılanamaması durumunda, müşteriler tatminsiz olur (Duman ve Öztürk, 2005; Güler, 2007; Jadhav ve Mor, 2010; Belpınar, 2014; Birdir ve Akgül, 2015). Bu çerçevede bireylerin veya gurupların ürünleri, hizmetleri ve deneyimleri seçmesi satın alması, tüketmesi ve kullandıktan sonraki süreçleri inceleyen "tüketici davranışı" başvurulması gereken bir bilimsel alandır (Koç, 2012).

Literatürde turizm sektöründe tüketici davranışlarının belirlenmesine yönelik çalışmalar (Öztürk ve Seyhan, 2005; Hayta, 2008; Emir ve Avan, 2010; İlban vd., 2011; Akkuş ve Cengiz, 2013; Örgün vd., 2013) oldukça fazladır. Ancak kültür turizmi kapsamında seyahat eden yerli turistlerin yiyecek ve içecek tüketim davranışları üzerine sınırlı sayıda araştırma (Güler, 2007; Okursoy ve Turan, 2014; Albayrak, 2014; Bekar ve K1lıç, 2015, Bucak ve Özkaya, 2015; Bayrakcı ve Akdağ, 2016) bulunmaktadır.

Bu çalışma, Dünya Miras Listesi içerisinde yer alan ve dünya ölçeğinde kültür turizmi adına önemli bir varış noktası olarak kabul edilen Safranbolu'ya gelen yerli turistlerin seyahat deneyiminde yiyecek-içecek beklentileri üzerine bir anlayış geliştirmeyi öngörmektedir. Çalışma, Safranbolu'yu ziyaret eden kültürel turistlerin seyahat nedenlerini belirlemek ve turist davranışı kapsamında seyahat nedenleri ile yiyecek-içecek beklentileri arasındaki ilişkinin test edilmesi açısından önem arz etmektedir. Özellikle, kültürel turistlerin yiyecek ve içecek işletmelerinden beklentilerinin ortaya konulması, kültür ve gastronomi turizmi düzeyinde literatür zenginliği oluşturabilecektir.

\section{LİTERATÜR İNCELEMESİ}

"Bir destinasyona yapılan kısa süreli seyahatler" olarak ifade edilebilen turizmin merkezinde turistler yer almaktadır. Bununla birlikte turizm literatüründe "turizmin gerçekleşmesini sağlayan insan unsuru" turist kavramı ile özdeşleştirilmektedir (Newsome vd., 2002; Durgun, 2006; Gülmez, 2012). Turizmin temel amac1; turist olarak tanımlanan insanların psikolojik tatmin duygusunu sağlamak olarak gösterilmektedir (Çuhadar, 2006). Seyahat ihtiyacının ortaya çıması ile turistin karşılaştıkları kişilerle ilişkiler ve seyahate çıktıktan sonra yaşadıkları turistik deneyimlerini değerlendirmeleri sırasında sergiledikleri davranışlar "turist davranışı" (Günlü, 2007) ile ilişkilendirilmekte ve turist davranışının, turistleri seyahate yönlendiren motivasyonlarda aranması düşünülmektedir (Akyurt ve Atay, 2009). Bununla birlikte bir turistin seyahat deneyimi sürecinde yiyecek ve içecekler, Şekil 1'de gösterilen biçimde resmedilmektedir (PSHE, 2013:68): 


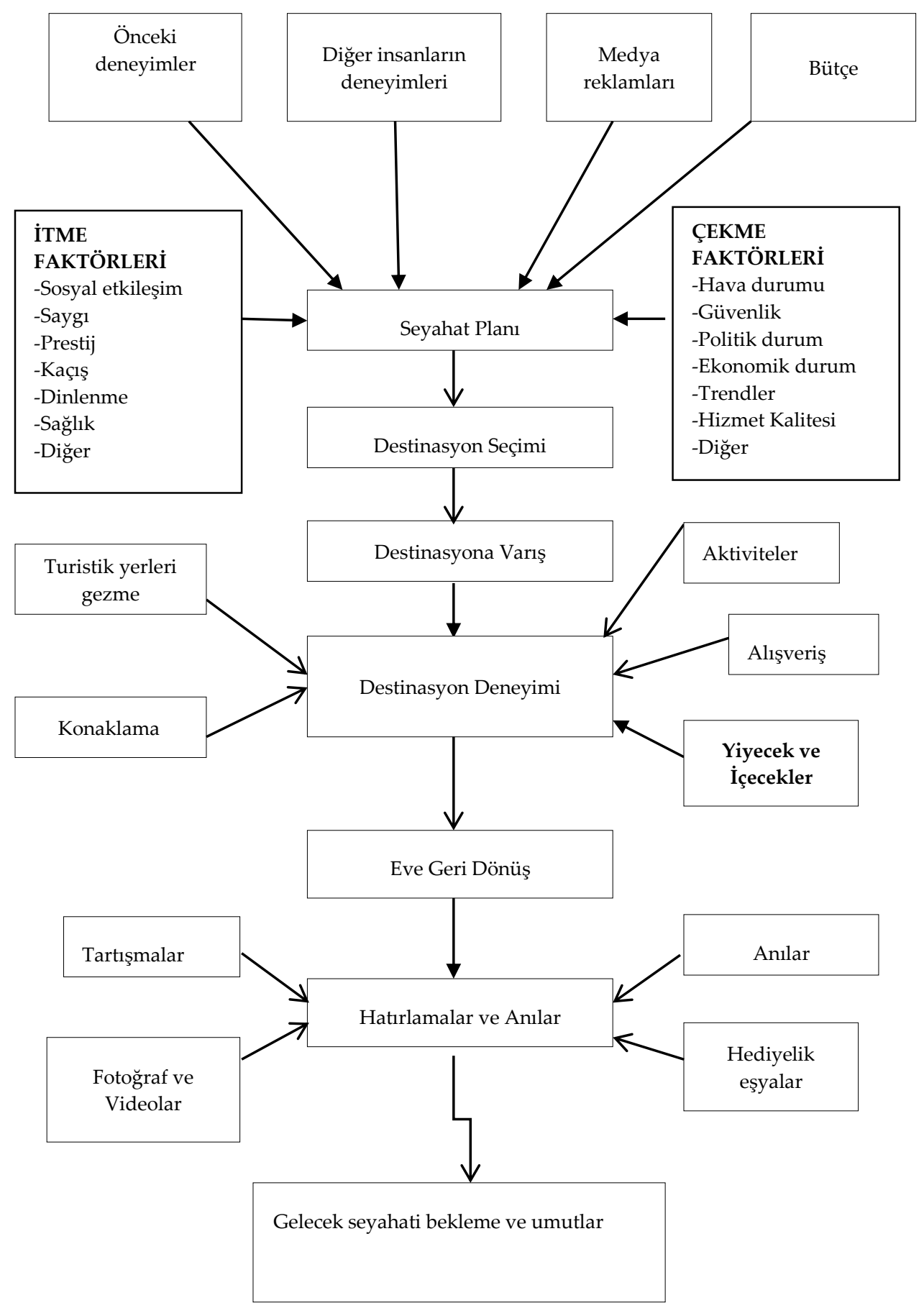

Şekil 1. Bir Turistin Seyahat Deneyimi

(PSHE, 2013:68'den uyarlanmıştır).

Yiyecek ve içecekler; fizyolojik, psiko-duygusal, sosyal ve sembolik bir ortamın bir parçası olup hijyenik ve besleyici değerlerine ek olarak, psiko-duyumsal ve sembolik özelliklere sahiptir. Bazı gıda maddeleri fantezinin ve konsantre sembolik erdemlerin (ekmek, şarap, tahıllar) temeldir. Paylaşılan ve başkalarıyla birlikte yenilen yemekler, temel bir sosyal bağlantıdır. Şampanya, havyar, viski, günlük tüketim için şarap veya geziler, çeşitli sosyal 
aktörlerin birbirlerini tanımlamalarına ve yaşam biçimlerini işaretlemelerine olanak tanıyan belirteçlerdir. Belli bir coğrafi alanda veya toplumun mutfak mirasında yiyecekler bazen de o toplumun sembolik bir amblemi olarak (Bessiere, 1998:23) kültürün vazgeçilmez öğeleridir.

Yeme ve içme, varlıkların hayatlarını devam ettirebilmeleri için tüketilmesi gereken maddelerdir. İnsanlar, nerede olursa olsun, her şeyden önce karnını doyurma çabası gösterseler de (Yergaliyeva, 2011:61) sosyal bir varlık olan insan için yeme-içme sadece biyolojik gereksinim olmayıp, birbirleriyle sohbet ettikleri, mutluluk ve üzüntülerini paylaştıkları, kutlamalar yaparak eğlenip kaynaştıkları ve sosyal ihtiyaçlarını karşıladıkları bir sosyal olgudur (Sormaz, 2015:49; Güneş vd., 2008:5). Bununla birlikte turizmde yiyecek tüketimi günlük beslenme ihtiyaçlarını karşılanma veya zevk şeklinde ortaya çıkabilmekte (Quan ve Wang, 2004) ve insanlar gereksinim duydukları yiyecekleri karşılama bağlamında yiyecek ve içecek işletmelerine başvurmaktadırlar.

Yiyecek ve içecek; bir bölgeye veya ülkeye yönelik seyahat tercihini ve doyumunu etkileyen bir unsur olmakla birlikte konaklama, destinasyonlarda sunulan aktiviteler, ulaşım ve diğer çekiciliklerin önemli bir parçasıdır (Seyitoğlu ve Çalışkan, 2014:35; Zağralı ve Akbaba, 2015:6635). Turistik harcamalar içerisinde konaklamadan sonra ikinci önemli kalemi ve seyahate ilişkin memnuniyet düzeyi ile yaşamsal ve süreklilik gösteren bir ihtiyacı karşıladığı için memnuniyet algısının oluşmasında en önemli unsurlardan biri olarak değerlendirilmektedir (Görkem, 2015:315). Bu gelişmelerle birlikte tüketicilerin trendleri sürekli olarak değişmekte, beklentilerin düzeyi artmaktadır Örneğin İngiltere'de yapılan araştırmada yiyecek ve içeceklere ilişkin değişimler şu şekilde sıralanmaktadır (http://cthresource.com):

- Misafir beklentileri daha karmaşık hale gelmekte,

- Gıda güvenliği kapsamında hijyene daha fazla önem verilmekte,

- Daha rahat, daha az resmi ve temalı restoranlar aranmakta,

- Etnik restoran ve yiyeceklere ilgi artmakta,

- Zincir işletme mutfakları büyümekte,

- Yiyeceklere ve içeceklere erişim kolaylığı artmakta,

- Kahve kültürüne ve zincirine ilgi artmakta,

- Ev yemekleri pişirme yerine dışarıdan hazır yemek sağlamak,

- İşletmelere satışa sunulacak yiyecekleri pişirme yerine dışarıdan temin etmek,

- Sağlıklı beslenmeye daha fazla odaklanma,

- Organik yiyecek tüketimine ilgi artmakta.

Ipsos Global Trends Raporu'nunda günümüz yemek sektörünü etkileyen ve etkileyecek olan 10 yeni trend; atıştırmak (aile ile birlikte yemek yeme yerine yoğun iş yaşamı nedeniyle yollarda yemek yeme), global lezzetlerin ortaya çıkması, yerlere olan sevgi maceraperest hibritler, sağlık ve zindelik yemek pişirmek/aşçllık, kişiselleştirme/uyarlama, tavizsiz lezzet, tarz ve atık farkındalığı olarak sıralanmaktadır (http://www.connectedvivaki.com). Bununla birlikte günümüz yiyecek ve içecek sektöründen beklenen davranışlar; hizmet kalitesi artışı, 
hizmet sunumlarında hijyen ve sanitasyon konularında daha çok duyarlılıktır (Biçici, 2008:20-21). Yiyecek ve içecek işletmeleri; insanların sürekli olarak yaşadığı yerlerde veya ikamet ettikleri bölgenin dışında farklı amaçlarla (dinlenme, eğlenme, iş, sağlık vb.) yaptıkları seyahatlerde yeme ve içme ihtiyaçlarının karşılanması için mal ve hizmet üreten ticari veya kurumsal işletmeler şeklinde veya konaklama işletmeleri içerisinde yeme ve içme ile ilgili ürünlerin satın alınması, depolanması, hazırlanması ve servise sunulmasından sorumlu birimler olarak öne çıkarılmaktadır (Özer, 2010; Sarışık, 2012). Yiyecek ve içecek işletmelerinin "yeme-içme amacıyla kendilerini ziyaret eden misafirlerinin isteklerini kalifiye personel, uygun ekipman ve donanımları ile karşılamanın önemini benimsemiş, ticari işletmeler" olması arzu edilmektedir (Kılıç ve Babat, 2011). Bu işletmelerin kaliteli hizmet sunumu adına belirli standartlarda hizmet veren ekonomik, kültürel ve sosyal kuruluşlar olması beklenmektedir (Duranoğlu vd., 2008:1075).

Müşterilerin tatmininde, müşteri memnuniyeti ile beklentileri arasında doğrudan bir ilişkili olduğu için memnuniyetin sağlanmasında beklentilerin bilinmesi gereklidir. Beklentiler, geçmiş deneyimlerle oluşan ürün performansı ya da önceden tahmin edilen düzeyleri olarak tanımlanmaktadır (Iskhakova, 2010:35). Beklentiler, kişiden kişiye değişkenlik göstermektedir. Müşteri beklentilerinin düzeyi, deneyimler sonucu edilen birikim ile belirlenmektedir. Önceki deneyimler olumlu olduğunda beklenti seviyesi yüksek, önceki deneyimler olumsuz olduğunda ise beklenti seviyesi düşük olur. $\mathrm{Bu}$ nedenle müşteri memnuniyeti, beklenti ile aldığı hizmet performansı arasındaki uyum ya da uyumsuzluk olarak da ifade edilmektedir (Burucuoğlu, 2011:17).

Yiyecek ve içecek kavramı hazırlanması nedeniyle endüstriyel bir konu olarak görünse de üretilmelerinden tüketilmelerine kadar sosyo-kültürel birçok davranışı içermesi nedeniyle turizm için bir zenginlik kaynağıdır. İnsanlar çeşitli zamanlarda, çok çeşitli amaçlarla (beslenme, eğlenme, özel gün kutlama, sosyalleşme, iş yemeği, yeni lezzetler keşfetme, snobizm, sosyokültürel etkinlikler içinde yer alma) yiyecek ve içecek işletmelerini ziyaret etmenin (Kılıç ve Babat, 2011:97) yanısıra bu işletmelerden temel beklentileri; daha kaliteli ve uygun fiyattan hizmet sunumu, nitelikli nazik personel, kaliteli araç gereç ve uygun atmosferdir (Akın, 2012:2). Turizm sektöründe konaklama ile birlikte yiyecek ve içecek hizmeti sunan işletmelerde her türlü servis çok iyi olsa bile, yiyecek-içecek servisi ve mutfağ1 kötü olan bir işletmenin müşterilerini memnun etmesi zordur. Bu bağlamada yiyecek-içecek hizmetleri konaklama işletmelerinin ve kalbi olarak da görülebilir (Sezgin, 2010:18). Çünkü konuklar; konakladıkları odayı, sabah çıkıp akşam yatmaya geldikleri için çok fazla önemsemezler. Ancak yeme ihtiyacı giderme bağlamında yiyecek ve içeceklerin çok iyi olmasını beklerler (Ateş, 2008:13). Yemek yenilirken aktif olan duyular ve keyif; bireylerin destinasyon seçimlerini, harcamalarını ve kalış sürelerini etkileyebilmekte, memnuniyeti, toplam elde edilen deneyimi ve dolaylı olarak da turizm gelirlerini artırabilen bir unsur olabilmektedir (Erdem ve Akkuş, 2013:637). Restoran gibi yiyecek ve içecek işletmelerinden hizmet satın alan misafirlerin kalite algılamaları konusunda farklıklar olduğu ve bu durumun kalite standardı oluşturmada sorunlara yol açtığı düşünülmektedir. Bununla birlikte misafirlerin kalite beklentilerinin şekillenmesinde işletmenin konumu, dekoru, otopark imkânları, hizmet sunum şekli, kabul ettiği misafirlerinin sosyal statüleri ve davranışları, servis personelinin dış görünüşüne dikkat çekilmektedir. Bunun yanı sıra satışa sunulan yemeklerin lezzeti, içerisinde kullanılan malzemelerin tazeliği ve siparişin temin süresi de kalite beklentisinde öne çıkartılmaktadır (Hatipoğlu ve Batman, 2014:28). Yiyecek ve içecek endüstrinin/işletmelerinin temel işlevi; hedef müşteri memnuniyeti olmak üzere insanlara yiyecek ve içecek hizmeti sunmaktır. Bununla birlikte bu işletmelerden hizmet alan misafirlerin fizyolojik (farklı çeşitlilikteki yiyecekleri tadabilme), ekonomik 
(gereksinim duyduğu ürün için evde hazırlamadan uygun fiyatın bulunması), sosyal (samimi bir ortamda dostça bir atmosfer), psikolojik (benlik saygısını yükseltme, kendini değerli ve sevilmeye değer görme), kolaylık (yemeği evde hazırlamanın zorluğu) yönden şu beklentilerinin karşılaması istenilmektedir (https://www.tutorialspoint.com; Cousins vd., 2014):

Müşteri odaklı hizmet anlayışı kapsamında müşterilerin beklentilerine yönelik mal ve hizmet sunabilen işletmelerin rakiplerine üstünlük sağlayabilmesi için müşterilerini iyi analiz etmeleri gerekmektedir. Özellikle yiyecek içecek sektörü gibi hızla gelişen ve rekabetin kendini hissettirdiği sektörlerde bu durum kendini çok hissettirmektedir. Dolayısıyla yiyecek ve içecek sektörü, artan rekabete bağlı olarak hizmetlerini sürekli çeşitlendirmeli, kalitesini yükseltmeli ve imajını müşterilerin zihninde canlı tutmalıdır (Güler, 2007:102). Yiyecek ve içecek sektörü hızlı bir gelişim sürecinde kendisini yenilemekte artan işletme sayısı ile birlikte misafirlerin bu işletmeleri tercih nedenleri (kaliteli ürün ve hizmet sunumunun önemsenmesi, fiyat, hizmetlerin soyut olması) değişmekte ve işletmeler arasındaki rekabeti artırmaktadır (Bucak ve Özkaya, 2015:40).

\section{YÖNTEM}

Turizm, memnuniyet üzerine kurulu bir sektördür. Bu sektörde konukların beklentilerinin karşılanması önem arz eder. Bu bağlamda turizm işletmelerinden hizmet satın alan veya almayı düşünen potansiyel turistlerinin beklentilerinin önceden öğrenilmesi, turizmde memnuniyeti artırıcı bir durum olarak görülebilir. Bu kapsamda bu araştırma, turizm arzının niteliğine müşteriler perspektifinden katkı sağlamak düşüncesiyle tasarlanmış, betimsel bir çalışmadır.

\section{Araştırmanın Problemi, Amacı ve Önemi}

Araştırmada bir destinasyonu ziyaret eden turistlerin seyahate çıkma nedenleri ile yiyecek ve içecek hizmetlerinden beklentileri arasındaki ilişkinin ortaya çıkartılması amaçlanmaktadır. Bu amaç doğrultusunda araştırmanın problemi "kültürel yerli turistlerin seyahat tercihleri ile yiyecek-içecek beklentileri arasında anlamlı bir ilişkinin bulunup, bulunmadığının test edilmesi" olarak belirlenmiştir. Bu araştırmanın temel amacı kültür turizmi destinasyonlarını ziyaret eden turistlerin seyahat tercihlerinin, yiyecek-içecek beklentilerinin ortaya çıkarılmasıdır. Bu ana amaçlarla birlikte çalışmanın hizmet sektörü kapsamında turizm arzının gelişimine katkı sağlaması, yiyecek ve içecek hizmeti sunmakta olan işletmeleri turistlerin seyahat nedenleri konusunda bilgilendirmesi, Safranbolu destinasyonunu ziyaret eden turistlerin seyahat tercihleri ve beklentileri konusunda yerel yönetimler başta olmak üzere ilgili kurum ve kuruluşlara bilimsel katkı sağlaması beklenmektedir.

\section{Araştırmanın Modeli ve Hipotezler}

Kültürel turistlerin seyahat tercihleri ve yiyecek-içecek beklentileri arasındaki ilişkinin test edilmesi kapsamında araştırma modeli Şekil 2'de gösterilen biçimde öngörülmüştür. 
Araştırma modelinde seyahat tercihleri bağımlı değişken, yiyecek-içecek beklentileri ise bağımsız değişkenler olarak öngörülmüş, araştırmaya yönelik hipotezler aşağıdaki şekilde belirlenmiştir:

$\mathrm{H}_{1}$ : Kültürel turistlerin seyahat tercihleri ile yiyecek-içecek beklentileri arasında anlamlı bir ilişki vardır.

$\mathrm{H}_{2}$ : Kültürel turistlerin seyahat tercihleri ile yemek beklentileri arasında anlamlı bir ilişki vardir.

$\mathrm{H}_{3}$ : Kültürel turistlerin seyahat tercihleri ile hijyen beklentileri arasında anlamlı bir ilişki vardir.

$\mathrm{H}_{4}$ : Kültürel turistlerin seyahat tercihleri ile hizmet sunumu beklentileri anlamlı bir ilişki vardir.

$\mathrm{H}_{5}$ : Kültürel turistlerin seyahat tercihleri ile salon atmosferi beklentileri arasında anlamlı bir ilişki vardır.

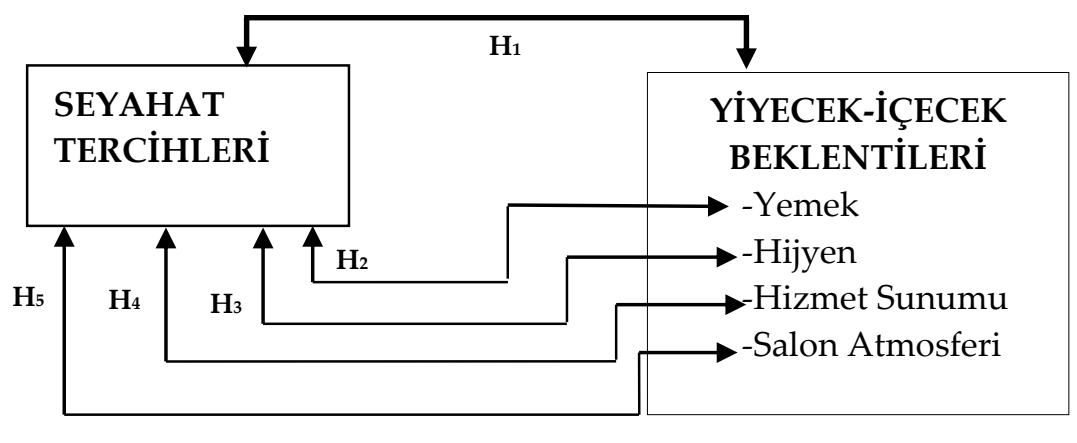

Şekil 2. Araştırma Modeli

\section{Araştırmanın Evreni ve Örneklem}

Bu araştırmada evreni, Karabük iline bağlı önemli bir kültürel cazibe merkezi olarak kabul edilen Safranbolu ilçesini 2014 yılı verileri kapsamında ziyaret eden 209.843 kişi oluşturmuştur. Bu verilerden hareketle zaman, maliyet ve ulaşılabilirlik unsurları dikkate alınarak örnekleme başvurulmuştur. Örneklem büyüklügü \%+-5 hata payında ve $Z$ değeri 1,96 olmak üzere 384 olarak tespit edilmiştir.

\section{Verilerin Toplanması ve Analizi}

Araştırma için kullanılması öngörülen veriler iki aşamalı bir süreçte toplanmıştır. Birinci aşamada literatür incelemesi kapsamında ikincil kaynaklardan turist davranışı, yiyecek ve içecek hizmetlerine yönelik tarama yapılmıştır. İkinci aşamada turistlerin seyahat tercihleri ve yiyecek-içecek beklentilerini belirlemek amaçlı anket ölçeği tasarlanmıştır. Anket ölçeği hazırlama sürecinde Arslan (2010), Akgöl (2012), Giritlioğlu (2012), Kanca (2012) ve Zağralı (2014) araştırmalarından faydalanılmıştır. Araştırma ölçeği için sorular akademisyen görüşü kapsamında düzenlenmiştir. Anket formu ön test kapsamında Safranbolu ziyaret eden 50 kültürel turiste kolayda örneklem yöntemi kapsamında Ocak 2016 döneminde uygulanmıştır. Ön test verileri, güvenirlik ve açıklayıcı faktör analizine tabi tutulmuştur. Analiz sonuçları kapsamında seyahat tercihleri bölümü için 6 soru yiyecek-içecek beklentileri içinse 7 soru çıkarılarak ölçek yeniden düzenlenmiştir. Düzenleme sonucunda 
anketin seyahat tercihleri bölümü için Cronbach Alpha değeri 0,92; yiyecek-içecek beklentileri içinse 0,84 olarak tespit edilmiştir. Yeniden düzenlenen anket; araştırmacı tarafından kolayda örneklem ve yüz yüze görüşme tekniği kapsamında Safranbolu'ya ziyaret gerçekleştirilen turistlere Şubat 2016-Haziran 2016 tarihleri arasında doldurulmuştur. Anket uygulaması aşamasında 420 turistle görüşülmüş ve anket dağıtılmıştır. Toplam 398 anketten geri dönüş sağlanmış (geri dönüş oranı \%95) ve araştırma kapsamında veriler kullanılabilir 391 anketten sağlanmıştır.

Araştırma için öngörülen ve araştırmada kullanılan anket üç kısımdan oluşmaktadır. Anketin ilk kısmında; turistlerin demografik ve diğer özelliklerini belirlemeye yönelik kişisel bilgilerin (cinsiyet, medeni durum, yaş, eğitim durumu, aylık gelir, meslek, kalış süresi ve ziyaret bilgi kaynağı) belirlenmesine yönelik sınıflama ölçeği; ikinci ve üçüncü bölümlerde ise kültürel turistlerin seyahat tercihleri ve yiyecek-içecek beklentilerini belirlenmesi kapsamında aralıklı ölçek ifadeleri kullanılmıştır. Bu ifadeler " $1=$ Katılmıyorum; $2=\mathrm{Az}$ Katılıyorum; 3=Kısmen Katılıyorum; 4=Katıllyorum; 5=Tamamen Katılıyorum" olmak üzere 5'li Likert Ölçeği şeklinde tasarlanmıştır. Anket verilerinin analizinde frekans ve yüzde analizi, aritmetik ortalama, standart sapma ve korelasyon analizi kullanılmıştır.

\section{BULGULAR}

Araştırma verilerinin analizi kapsamında ilk olarak kültürel yerli ziyaretçilere yönelik demografik ve diğer özellikler açısından tanımlayıcı bilgiler yüzde ve frekans analizi kapsamında sıralanmış ve Tablo 1'de gösterilen biçimde tespit edilmiştir. Katılımcılara ilişkin tanımlayıcı bilgilerde cinsiyet yönünden kadınlar (\%54,5), medeni durum yönünden bekarlar $(\% 59,6)$, yaş yönünden 24 ve altı $(\% 37,9)$, eğitim durumu yönünden ön lisans ve lisans (\%62,7), gelir durumu yönünden 1001-2000 TL (\%39,9), meslek yönünden diğer meslek grubu (\%54,7), kalış süreleri yönünden 4 gün ve üzeri (\%34) ve seyahate çıktığı kişi sayısı değişkeninde 2 kişi ile katılanların $(\% 37,1)$ öne çıktığı söylemek mümkündür.

Tablo 1. Katılımcıların İlişkin Tanımlayıcı Bilgiler $(\mathrm{n}=391)$

\begin{tabular}{|c|c|c|c|c|}
\hline Değişkenler & Gruplar & $\mathbf{f}$ & $\%$ & $\begin{array}{c}\text { Kümülatif } \\
\%\end{array}$ \\
\hline \multirow{2}{*}{ Cinsiyet } & Kadin & 213 & 54,5 & 54,5 \\
\hline & Erkek & 178 & 45,5 & 100 \\
\hline \multirow{2}{*}{ Medeni Durum } & Bekar & 233 & 59,6 & 59,6 \\
\hline & Evli & 158 & 40,4 & 100 \\
\hline \multirow{4}{*}{ Yaş } & 24 ve alt1 & 148 & 37,9 & 37,9 \\
\hline & $25-34$ & 118 & 30,2 & 68,1 \\
\hline & $35-44$ & 66 & 16,9 & 85,0 \\
\hline & 45 ve üzeri & 59 & 15,1 & 100 \\
\hline \multirow{4}{*}{ Meslek } & Memur & 89 & 22,8 & 22,8 \\
\hline & İşçi & 57 & 14,6 & 37,4 \\
\hline & Emekli & 31 & 7,9 & 45,3 \\
\hline & Diğer & 214 & 54,7 & 100 \\
\hline \multirow{3}{*}{ Eğitim Durumu } & İlköğretim & 55 & 14,1 & 14,1 \\
\hline & Ortaöğretim & 91 & 23,3 & 37,4 \\
\hline & Ön Lisans & 143 & 36,6 & 73,9 \\
\hline
\end{tabular}




\begin{tabular}{|l|l|c|l|c|}
\hline & Lisans & 102 & 26,1 & 100 \\
\hline \multirow{4}{*}{ Gelir Durumu } & 1000 TL ve altı & 139 & 35,5 & 35,5 \\
\cline { 2 - 5 } & $1001-2000$ TL & 156 & 39,9 & 75,4 \\
\cline { 2 - 5 } & 2001 TL ve üzeri & 96 & 24,6 & 100 \\
\hline \multirow{4}{*}{ Kalış Süresi } & 1 gün & 126 & 32,2 & 32,2 \\
\cline { 2 - 5 } & 2 gün & 92 & 23,5 & 55,7 \\
\cline { 2 - 5 } & 3 gün & 40 & 10,2 & 65,9 \\
\cline { 2 - 5 } & 4 gün ve üzeri & 133 & 34,1 & 100 \\
\hline \multirow{4}{*}{$\begin{array}{l}\text { Seyahate Çıktığı Kişi } \\
\text { Sayısı }\end{array}$} & 1 & 145 & 37,1 & 37,1 \\
\cline { 2 - 5 } & 2 & 113 & 28,9 & 66,0 \\
\cline { 2 - 5 } & 3 & 54 & 13,8 & 79,8 \\
\cline { 2 - 5 } & 4 ve üzeri & 79 & 20,2 & 100 \\
\hline
\end{tabular}

Araştırma verilerinin analizi kapsamında ikinci olarak Safranbolu'ya ziyaret gerçekleştiren yerli ziyaretçilerin seyahat tercihlerinin belirlenmesine yönelik faktör analizi öngörülmüştür. Seyahat tercihlerine yönelik faktör analizi sonucunda dört boyut (öğrenme, macera, rahatlama, etkileşim) ortaya çıkmıştır. Bu boyutlara ilişkin 9 yargı için KMO Örneklem Ölçüm Değer Yeterliliği katsayısı 0,77, Bartlett's Kürsellik Testi anlamlılık düzeyi; $\mathrm{p}=0,000$, varyans açılama oranı; 76,06 ve toplam güvenilirlik kat sayısı; 0,82 olarak belirlenmiştir (Tablo 2).

Tablo 2. Kültürel Turistlerin Seyahat Tercihlerine Yönelik Faktör Analizi

\begin{tabular}{|l|c|c|c|c|c|}
\hline Faktör & $\bar{x}$ & $\sigma$ & $\begin{array}{c}\text { Yaktör } \\
\text { Yü }\end{array}$ & $\begin{array}{c}\text { Cronba } \\
\text { ch } \\
\text { Alpha }\end{array}$ & $\begin{array}{c}\text { Varyans } \\
\text { Açılama } \\
(\%)\end{array}$ \\
\hline Öğrenme & $\mathbf{4 , 0 0}$ & $\mathbf{0 , 9 3}$ & & & $\mathbf{2 1 , 8 9}$ \\
\hline $\begin{array}{l}\text { Ziyaret ettiğim yerde yöresel yemekleri tatmak } \\
\text { isterim. }\end{array}$ & 4,11 & 1,11 & 0,850 & 0,806 & \\
\hline $\begin{array}{l}\text { Ziyaret ettiğim yerin kültürünü öğrenmek } \\
\text { isterim. }\end{array}$ & 4,05 & 1,18 & 0,746 & 0,801 & \\
\hline $\begin{array}{l}\text { Ziyaret ettiğim yerdeki geleneksel yaşamı } \\
\text { deneyimlemek isterim. }\end{array}$ & 3,84 & 1,17 & 0,628 & 0,803 & \\
\hline Macera & $\mathbf{3 , 9 1}$ & $\mathbf{1 , 9 9}$ & & $\mathbf{2 0 , 1 4}$ \\
\hline $\begin{array}{l}\text { Ziyaret ettiğim yerde keşfedilmemiş yerleri } \\
\text { gezmeyi severim. }\end{array}$ & 3,89 & 1,17 & 0,828 & 0,799 & \\
\hline $\begin{array}{l}\text { Ziyaret ettiğim yerde keşfedilmemiş̧ } \\
\text { restoranları tercih ederim. }\end{array}$ & 3,86 & 1,27 & 0,804 & 0,804 & \\
\hline $\begin{array}{l}\text { Ziyaret ettiğim yerde farklı aktivitelere } \\
\text { katılmayı severim. }\end{array}$ & 3,97 & 1,19 & 0,674 & 0,808 & \\
\hline Rahatlama & $\mathbf{3 , 2 1}$ & $\mathbf{1 , 1 3}$ & & & $\mathbf{1 9 , 7 2}$ \\
\hline $\begin{array}{l}\text { Ziyaret ettiğim yerde bilgiden çok değişiklik ve } \\
\text { eğlence ararım. }\end{array}$ & 3,52 & 1,31 & 0,955 & 0,815 & \\
\hline
\end{tabular}




\begin{tabular}{|l|l|l|l|l|l|}
\hline $\begin{array}{l}\text { Ziyaret ettiğim yerdeki eğlence mekanlarını } \\
\text { gezmeyi severim. }\end{array}$ & 2,90 & 1,53 & 0,953 & 0,839 & \\
\hline Etkileşim & $\mathbf{3 , 6 2}$ & $\mathbf{1 , 1 5}$ & & & $\mathbf{1 4 , 2 9}$ \\
\hline $\begin{array}{l}\text { Ziyaret ettiğim yerde yerli halkın evlerinde } \\
\text { misafir olmaktan onur duyarım. }\end{array}$ & 3,41 & 1,40 & 0,897 & 0,801 & \\
\hline $\begin{array}{l}\text { Ziyaret ettiğim yerde yerli halk ile tanışmayı } \\
\text { severim. }\end{array}$ & 3,82 & 1,21 & 0,615 & 0,792 & \\
\hline $\begin{array}{l}\text { Toplam Cronbach Alpha/Varyans Açıklama } \\
\text { (\%) }\end{array}$ & & & & $\mathbf{0 , 8 2}$ & $\mathbf{7 6 , 0 6}$ \\
\hline
\end{tabular}

KMO Örneklem Ölçüm Değer Yeterliliği: 0,77

Bartlett's Kürsellik Testi (Chi-Square / df / Sig): 2016,401/45/ 0,000

Kültürel turistlerin yiyecek-içecek beklentilerinin belirlenmesine yönelik olarak gerçekleştirilen faktör analizinde dört boyut (yemek, hijyen, hizmet sunumu, salon atmosferi) ortaya çıkmıştır. Bu boyutlara ilişkin aritmetik ortalama, standart sapma ve varyans açıklama oranları Tablo 3'te sunulmaktadır. Kültürel turistlerin yiyecek-içecek beklentilerine ilişkin faktör analizi için 12 ifadeye ait 4 faktörün KMO katsayısı 0,88, Bartlett Sphericity testi anlamlılık düzeyi; $p=0,000$, varyans açıllama oranı; 72,05 ve toplam güvenilirlik kat sayısı; 0,91 olarak belirlenmiştir.

Tablo 3. Kültürel Turistlerin Yiyecek-İçecek Beklentilerine Yönelik Faktör Analizi

\begin{tabular}{|l|c|c|c|c|l|}
\hline Faktör & $\bar{x}$ & $\sigma$ & $\begin{array}{l}\text { Faktör } \\
\text { Yükü }\end{array}$ & $\begin{array}{c}\text { Cronbach } \\
\text { Alpha }\end{array}$ & $\begin{array}{l}\text { Varyans } \\
\text { Açılama } \\
(\%)\end{array}$ \\
\hline Yemek & $\mathbf{4 , 1 5}$ & $\mathbf{0 , 8 3}$ & & & $\mathbf{2 2 , 0 1}$ \\
\hline $\begin{array}{l}\text { Yemeklerin doyuruculuğunu } \\
\text { önemserim. }\end{array}$ & 4,15 & 1,10 & 0,770 & 0,906 & \\
\hline $\begin{array}{l}\text { Yemeklerin besleyiciliğini } \\
\text { önemserim. }\end{array}$ & 4,07 & 1,06 & 0,758 & 0,907 & \\
\hline Yemeklerin çeşitliliğini önemserim & 4,25 & 1,05 & 0,691 & 0,906 & \\
\hline Yemeklerin fiyatlarını önemserim. & 4,18 & 1,06 & 0,633 & 0,910 & \\
\hline $\begin{array}{l}\text { Yiyeceklerin organikliğini } \\
\text { önemserim. }\end{array}$ & 4,09 & 1,09 & 0,599 & 0,907 & $\mathbf{2 1 , 3 0}$ \\
\hline Hijyen çalışanlarının hijyen & 4,38 & 1,07 & 0,805 & 0,904 & \\
\hline $\begin{array}{l}\text { Restoran } \\
\text { kurallarına uymasını önemserim. }\end{array}$ & $\mathbf{4 , 4 0}$ & $\mathbf{0 , 8 8}$ & & & \\
\hline $\begin{array}{l}\text { Yiyecek ve içecek servisi verilen } \\
\text { salonun temizliğini önemserim. }\end{array}$ & 4,37 & 1,03 & 0,771 & 0,904 & \\
\hline
\end{tabular}




\begin{tabular}{|c|c|c|c|c|c|}
\hline $\begin{array}{l}\text { Yiyecek içecek işletmelerinde } \\
\text { bulunan tuvalet ve lavaboların temiz } \\
\text { olmasını önemserim. }\end{array}$ & 4,39 & 1,02 & 0,732 & 0,904 & \\
\hline $\begin{array}{l}\text { Yiyecek ve içeceklerin sunumunda } \\
\text { kullanılan servis ekipmanlarının } \\
\text { temiz olmasını önemserim. }\end{array}$ & 4,45 & 0,99 & 0,629 & 0,906 & \\
\hline Hizmet Sunumu & 4,27 & 0,01 & & & 16,74 \\
\hline $\begin{array}{l}\text { Restoran çalışanlarının ilgisini } \\
\text { önemserim. }\end{array}$ & 4,30 & 1,02 & 0,838 & 0,905 & \\
\hline $\begin{array}{l}\text { Yemeklerinin hızlı servis edilmesini } \\
\text { önemserim. }\end{array}$ & 4,23 & 1,10 & 0,801 & 0,905 & \\
\hline Salon Atmosferi & 3,96 & 0,95 & & & 11,99 \\
\hline $\begin{array}{l}\text { Yemek salonlarının modernliği } \\
\text { önemserim. }\end{array}$ & 3,87 & 1,16 & 0,773 & 0,914 & \\
\hline $\begin{array}{l}\text { Yemek salonunun sakin olmasını } \\
\text { önemserim. }\end{array}$ & 4,05 & 1,13 & 0,745 & 0,912 & \\
\hline $\begin{array}{l}\text { Toplam Cronbach Alpha/Varyans } \\
\text { Açıllama (\%) }\end{array}$ & & & & 0,91 & 72,05 \\
\hline
\end{tabular}

KMO Örneklem Ölçüm Değer Yeterliliği: 0,88

Bartlett's Kürsellik Testi (Chi-Square / df / Sig): 2900,041/78 /0,000

Safranbolu destinasyonunu ziyaret eden kültürel turistlerin seyahat tercihleri ve yiyecekiçecek beklentileri arasında bir ilişkinin bulunup-bulunmadığını test edilmesi kapsamında araştırma verileri için Korelasyon Analizi öngörülmüştür. İki farklı değişken arasındaki ilişki veya bağımlılık durumunu açılamak adına tercih edilebilen korelasyon analizinde, korelasyon katsayısı (r), +/- 1 arasında bir değer olarak kabul edilmekte, katsayının eksi olmasında negatif yönlü bir ilişki; artı çıkması halinde ise pozitif ilişkiden söz edilmektedir. Ayrıca " $r$ " değerinin 0,00-0,29 arasında olması "düşük", 0,30-0,69 arasında olması "orta", 0,70 ve üzeri olması durumu ise "yüksek" düzeyde ilişkinin bulunduğu şeklinde değerlendirilmektedir (Ural ve Kılıç, 2006). 
Tablo 4. Kültürel Turistlerin Seyahat Tercihi ve Yiyecek-İçecek Beklentileri İlişkisine Yönelik Korelasyon Analizi $(\mathrm{n}=391)$

\begin{tabular}{|c|c|c|c|c|c|c|c|}
\hline \multicolumn{2}{|l|}{ Boyutlar-Faktörler } & A & B & C & $\mathrm{D}$ & E & $\mathrm{F}$ \\
\hline \multirow{2}{*}{ Seyahat Tercihleri (A) } & $\mathrm{r}$ & 1 & & & & & \\
\hline & $\mathrm{p}$ & & & & & & \\
\hline \multirow{2}{*}{ Yiyecek-İçecek Beklentileri (B) } & $\mathrm{r}$ & 0,566 & 1 & & & & \\
\hline & $\mathrm{p}$ & $0,000^{*}$ & & & & & \\
\hline \multirow{2}{*}{ Yemek (C) } & $\mathrm{r}$ & 0,588 & 0,833 & 1 & & & \\
\hline & $\mathrm{p}$ & $0,000^{*}$ & $0,000^{*}$ & & & & \\
\hline \multirow{2}{*}{ Hijyen (D) } & $\mathrm{r}$ & 0,486 & 0,852 & 0,636 & 1 & & \\
\hline & $\mathrm{p}$ & $0,000^{*}$ & $0,000^{*}$ & $0,000^{*}$ & & & \\
\hline \multirow{2}{*}{ Hizmet Sunumu (E) } & $\mathrm{r}$ & 0,380 & 0,824 & 0,562 & 0,668 & 1 & \\
\hline & $\mathrm{p}$ & $0,000^{*}$ & $0,000^{*}$ & $0,000^{*}$ & $0,000 *$ & & \\
\hline \multirow{2}{*}{ Salon Atmosferi (F) } & $\mathrm{r}$ & 0,420 & 0,763 & 0,569 & 0,497 & 0,426 & 1 \\
\hline & $\mathrm{p}$ & $0,000^{*}$ & $0,000^{*}$ & $0,000^{*}$ & $0,000^{*}$ & $0,000 *$ & \\
\hline
\end{tabular}

$*(\mathrm{p}<0,001)$

Tablo 4'te sunulan kültürel turistlerin seyahat tercihi ve yiyecek-içecek beklentileri ilişkisine yönelik Korelasyon Analizi bulgularına göre;

Kültürel turistlerin seyahat tercihleri ve yiyecek-içecek beklentileri arasında " $r$ " değeri; 0,566 olduğu için orta düzeyde $(0,30<r<0,69)$ pozitif yönlü doğrusal ilişkinin varlığından söz etmek mümkündür. $\mathrm{Bu}$ ilişki kapsamında araştırma için önerilen $\mathrm{H}_{1}$ hipotezi kabul edilmiştir. Ayrıca kültürel turistlerin seyahat tercihlerinin artması halinde $\% 56,2$ oranında yiyecekiçecek beklentilerini artıracağını söylemek uygun olacaktır.

Kültürel turistlerin seyahat tercihleri ve yemek beklentileri arasında " $r$ " değeri; 0,588 olmak üzere orta düzeyde $(0,30<\mathrm{r}<0,69)$ pozitif yönlü doğrusal ilişkinin varlığından söz etmek mümkündür. Bu ilişki kapsamında araştırma için önerilen $\mathrm{H}_{2}$ hipotezi bu araştırma için kabul edilmiştir.

Kültürel turistlerin seyahat tercihi ve hijyen beklentileri arasında " $r$ " değeri; 0,486 olmak üzere orta düzeyde $(0,30<\mathrm{r}<0,69)$ pozitif yönlü doğrusal ilişkinin varlığından söz etmek mümkündür. Bu ilişki kapsamında araştırma için önerilen $\mathrm{H}_{3}$ hipotezi kabul edilmiştir.

Kültürel turistlerin seyahat tercihi ve hizmet sunumu beklentileri arasında " $\mathrm{r}$ " değeri; 0,380 olmak üzere orta düzeyde $(0,30<r<0,69)$ pozitif yönlü doğrusal ilişkinin varlığından söz etmek mümkündür. Bu ilişki kapsamında araştırma için önerilen $\mathrm{H}_{4}$ hipotezi kabul edilmiştir.

Kültürel turistlerin seyahat tercihi ve salon atmosferi beklentileri arasında " $r$ " değeri; 0,420 olmak üzere orta düzeyde $(0,30<r<0,69)$ pozitif yönlü doğrusal ilişkinin varlığından söz etmek mümkündür. Bu ilişki kapsamında araştırma için önerilen $\mathrm{H}_{5}$ hipotezi kabul edilmiştir. 


\section{TARTIŞMA, SONUÇ VE ÖNERILER}

Turizm sektöründe yiyecek ve içeceklerin servisinde hizmet sunumu ve müşteri deneyimi olmak üzere iki temel boyut vardır. Hizmet sunumu, yiyecek ve içeceklerin müşteri ile buluşturulması; müşteri deneyimi ise daha çok memnuniyet ve işletmeyi yeniden ziyaret etmesi ile ilgili bir durumdur. Bu bağlamda müşterilerin yiyecek ve içeceklerle buluşturulması ve memnuniyet beklentilerinin öğrenilmesi bir gerekliliktir.

Yiyecek ve içecekler bir turistin seyahat sürecinde gerçekleştirdiği harcama kalemleri içerisinde ilk üç sırada yer almaktadır. Ancak kalite beklentisi ve memnuniyet sürecinde müşterilerin en az hoşnut oldukları alanı yiyecek ve içecekler oluşturmaktadır (Aksu vd., 2009). Bununla birlikte yiyecek ve içecek operasyonlarının ana amacı; müşterilerin ihtiyaçlarını karşılamak ve memnuniyetlerini sağlamaktır. Yiyecek ve içecek hizmetleri kapsamında müşteri memnuniyetini sağlama adına müşterilerin fizyolojik (beslenme ihtiyac1), sosyal (başka bireylerle etkileşim), ekonomik (fiyat uygunluğu), psikolojik (sayg1 görme) ve kolaylık (evde yemek pişirmek zorunda kalmama) yönünde beklentilerinin karşılanmasının önemine dikkat çekilmektedir (Cousins vd., 2014).

Literatürde kültürel turistlere yönelik önceki çalışmalarda (Silberberg, 1995; Kızılırmak ve Kurtuldu, 2005; Öter ve Özdoğan, 2005; Altunel ve Kahraman, 2012) kültür turistlerinin çoğunlukla genç, kalabalık bir aile yapısına sahip olmayan eğitim seviyeleri yüksek ziyaretçilerden oluştuğu, kadınların, gelir durumu yüksek olan ve orta yaş grubunda olan turistlerin kültürel aktivitelere katılma konusuna daha çok istekli olduğu, destinasyonlarda kalış sürelerinin diğer turistlere göre daha fazla olduğu, kariyer sahibi, seyahat etmedeki esas amaçlarının destinasyonun kültürü hakkında yeni bilgiler öğrenme ve yörenin kültürünü deneyimleme olduğu, yılda birden fazla tatile çıktıkları ve genellikle kalabalık arkadaş ve tur grubu eşliğinde lüks otellerde yarım ve tam pansiyon konaklamayı tercih ettikleri, soğukkanlı bir kişiliğe ve turizm bilincine sahip kişiler oldukları, kişisel gelişime önem verdikleri ve diğer kültürleri tanıma yönünde daha çok istekli oldukları, kültürel amaçlı seyahate çıkan turistlerin anlık satın alma davranışında psikolojik faktörlerden daha çok etkilendikleri, deneyimlerini ve algılamalarını etkileyen temel özellikler; sosyal etkileşim, yerel otantiklik, hizmet, kültürel miras ve destinasyondaki sorunlar olarak belirlenmiştir. Bu araştırmada ise kültür turizmine dahil olan yerli ziyaretçilerin genel profil özellikleri; kadınlar, bekarlar, 24 ve altı yaş grubu, ön lisans ve lisans mezunları, 1001-2000 TL gelir grubu, diğer meslek grubu, 4 gün ve üzeri kalanlar ve seyahate 2 kişi ile katılanlar şeklinde tespit edilmiştir. Yerli ziyaretçilerin ziyaret öncelikleri ise kültür, macera ve eğlence öncelik sırasında toplanmıştır. Kültür boyutunda kültürü öğrenme, yöresel yemekleri tatma isteği, yerli halk ile tanışma ve geleneksel yaşamı deneyimleme öne çıkmıştır. Macera boyutunda keşfedilmemiş yerleri gezme, farklı aktivitelere katılma ve yemek için restoranları önceden keşfedilmemiş yerleri seçme belirleyici öğeler olmuştur. Eğlence alt boyutu içinse temel beklentiler; eğlence mekanlarını gezme, eğlence programlarına dahil olma ve bilgiden çok değişiklik ve eğlence aranması olmuştur.

Yerli ve yabancı turistlerle yönelik olarak gerçekleştirilen yiyecek ve içecek araştırmalarında (Gürbüz, 2003; Quan ve Wang, 2004; Şanlıer, 2005; Giritlioğlu, 2012; Albayrak, 2014) yiyecek ve içecek hizmetlerinde turistin eğitim düzeyi arttıkça memnuniyetinin arttığı, yiyecek ve içeceklerin günlük beslenme ihtiyacını karşılama dışında zevk için de tüketilebildiği, yerli turistlerin lezzetli, doyurucu, iştah açıcı, güzel görünüşlü hoş kokulu ve fazla kalorili yemekleri tercih ettiği, yiyecek ve içecek hizmet kalitesini; dostluk, hijyen, doğru hizmet sunumu, rahatlık, fiziksel görünüm, erişilebilirlik ve iç mekan tasarımının etkilediği, beklentilerin yiyecek ve içecek işletmesinin tipine göre farklılaştı̆̆ı, kültürel turistlerin 
beklentileri algılarından daha yüksek seviyede olduğu, yiyecek ve içecek hizmetlerinde yemeklerin çok kalorili ve yağlı olması, menülerde diyabetik ürünlerin bulunmaması, yiyeceklerin içinde yer alan besin öğelerinin yazılmaması, yemeklerin çok tuzlu olması en çok karşılaşılan sorunlar olduğu, yabancı turistlerin yöresel yiyecek ve içecekleri deneyimleme oranının düşük olduğu, kültürel turistlerin yiyecek ve içecek işletmelerinden kalite beklentileri; yemeklerin tazeliği, servis sıcaklığı, görünümü, tadı ve hizmet kalitesinden oluştuğu, hijyen beklentilerinin yemek yenilen alanın temizliği ve düzenini, kullanılan servis araçlarının temizliği ile ilgili olduğu, yiyecek ve içecek hizmetlerinde fiyat uygunluğu, servis saatleri, porsiyon büyüklüğünün önemsendiği, yabancı turistlerin yemeklere yönelik beğeni düzeyleri; lezzet, görünüş, kalite, porsiyon, besin değeri, yağ-şeker miktarı, çeşitlilik ve genel hijyen durumu olduğu ve yerel yemeğin bir destinasyonu tekrar ziyaret etmede etkilediği olduğu olarak belirtilmektedir.

Kültürel turizm temalı destinasyonlarda bulunan yiyecek ve işletmelerinde müşteri memnuniyeti artırma ve müşteri beklentisini karşılama adına turistlerin seyahat tercihlerini dikkate alarak yiyecek ve içecek hizmet sunumlarında turistlerin değişen beklenti ve isteklerini, turistlerin profillerini ile yiyecek ve içecek trendlerini sürekli takip ederek bu beklenti ve isteklerine uygun hizmet anlayışı geliştirmelidir. Özellikle yemeklerin çeşitliliği, tazeliği, organikliği, fiyatı ve hijyenik koşullarda hazırlanmasını olduğundan yiyecek ve içecek işletme yöneticileri, bu beklentiler konusunda titiz davranmaları gerekmektedir. Yiyecek ve içecek işletmeleri hizmet salonlarını turistlerin beklentilerine uygun modernlikte olmasına özen göstermelidir. Turistlerin istek ve beklentileri birbirinden farklı olduğundan değişik hizmet sunumlariyla turistlerin tüm bireysel isteklerine cevap verebilmeye çalışılmalıdır. Bireysel hizmetin ön planda olduğu yiyecek ve içecek işletmelerinde işgörenler turistlere güven verme adına menüde yer alan bilgilerle, sunumu yapılan hizmetlerde tutarlılık (porsiyon büyüklüğü, fiyat, çeşitlilik vb.) oluşturulmalıdır. Menülerinde yerel yemekleri daha fazla öne çıarılması, hijyen ve servis kuralları ile ilgili hizmet içi eğitimler verilmesi, hizmetlerini sürekli çeşitlendirilmesi, kalitenin yükseltilmesi ve imajını müşterilerin zihninde canlı tutulması önem arz etmektedir.

$\mathrm{Bu}$ çalışmada, kültür turizmi kapsamında yerli ve yabancı turistler düzeyinde önemli bir varış noktası haline gelmiş olan Safranbolu ilçesini ziyaret eden kültürel turistlerin seyahat tercihleri ile yiyecek-içecek beklentilerine yönelik bir çerçeve oluşturulmuştur. Çalışmanın Türkiye'deki diğer kültürel çekim merkezlerine yol gösterici olması beklenmektedir. Bununla birlikte gelecekteki benzer araştırmalarda yabancı kültürel turistlere yönelik benzer çalışmaların yapılması farklı öngörüler oluşturabilecektir. Bu anlamda çalışmada geliştirilen ölçeğinin kullanılması halinde farklı sonuçlara ulaşılabilir.

\section{KAYNAKÇA}

Akgöl, Y. (2012). Gastronomi Turizmi ve Türkiye'yi Ziyaret Eden Yabancı Turistlerin Gastronomi Deneyimlerinin Değerlendirilmesi. Yayınlanmamış Yüksek Lisans Tezi, Mersin Üniversitesi Sosyal Bilimler Enstitüsü, Mersin.

Akın, A. (2012). Turizm İşletme Belgeli Yiyecek İçecek İşletmelerinde Uygulanabilir Fiyatlama Yöntemlerinin Belirlenmesine Yönelik Bir Araştırma: Gaziantep Örneği. Yayınlanmamış Yüksek Lisans Tezi, Niğde Üniversitesi Sosyal Bilimler Enstitüsü, Niğde.

Akkuş, Ç. ve Cengiz, G. (2013). Beş Yıldızlı Otel Restoranları Müşteri Memnuniyeti: Erzurum İlinde Bir Araştırma. Journal of Yasar University, 8(31):5229-5252. 
Akyurt, H. ve Atay, L. (2009). Destinasyonda İmaj Oluşturma Süreci. Aksaray Üniversitesi İ̈BF Dergisi, 1(1):1-14.

Altunel, C. ve Kahraman, N. (2012). Kültür Turisti Tipolojilerinin Belirlenmesi: İstanbul Örneği. Anatolia: Turizm Araştırmaları Dergisi, 23(1):7-18.

Albayrak, A. (2014). Üçüncü Yaş Turistlerinin Otellere Bağlı Restoranlarında Yiyecek ve İçecekler İle İlgili Karşılaştıkları Sorunlar. Balıkesir Üniversitesi Sosyal Bilimler Enstitüsü Dergisi, 17(31):345-368.

Arslan, Ö. (2010). Yabancı Turistlerin Yiyecek İçecek İşletmeleri, Personeli ve Türk Mutfağına İlişkin Görüşlerinin Değerlendirilmesi: Alanya Örneği. Yayınlanmamış Yüksek Lisans Tezi, Gazi üniversitesi Eğitim Bilimleri Enstitüsü, Ankara.

Ateş, A. (2008). Otel İşletmelerinde Yöneticilerin İş Etiğine Yaklaşımları ve İzmir İlinde Dört ve Beş Yıldızlı Otel İşletmelerinde Bir Uygulama. Yayınlanmamış Yüksek Lisans Tezi, Dokuz Eylül Üniversitesi Sosyal Bilimler Enstitüsü, İzmir.

Avcıkurt, C., Sarığlan, M. ve Girgin, G. K. (2007). Yiyecek-İçecek Olgusuna Sosyolojik Bir Bakış. 1.Ulusal Gastronomi Sempozyumu ve Sanatsal Etkinlikler, Antalya.

Ayaz, N. (2012). Kırsal Turizm ve Paydaşları: Belediye Başkanlarının Tutumlarına Yönelik Bir Araştırma. Yayımlanmamış Doktora Tezi, Gazi Üniversitesi Eğitim Bilimleri Enstitüsü, Ankara.

Bayrakcı, S. ve Akdağ, G. (2016). Yerel Yemek Tüketim Motivasyonlarının Turistlerin Tekrar Ziyaret Eğilimlerine Etkisi: Gaziantep'i Ziyaret Eden Yerli Turistler Üzerine Bir Araştırma. Anatolia: Turizm Araştırmaları Dergisi, 27(1):96-110.

Bekar, A., Kılıç, B. ve Şahin, Ö. (2011). Gastro Turizm Ve Turistik Tüketicilerin Gastro Turizme Yönelik Görüşleri. 12. Ulusal Turizm Kongresi. 30 Kasım-4 Aralık, Akçakoca: 516-524.

Bekar, A. ve Kılıç, B. (2014). Turistlerin Gelir Düzeylerine Göre Destinasyondaki Gastronomi Turizmi Etkinliklerine Katılımları. Uluslararası Sosyal ve Ekonomik Bilimler Dergisi, 4(1):19-26.

Bekar, A. ve Kılıç, B. (2015). Hizmet Kalitesi Memnuniyet İlişkisi: Üniversite Kampüsünde Faaliyet Gösteren Yiyecek İçecek İşletmelerinde Karşılaştırmalı Bir Uygulama. Sosyal ve Beşeri Bilimler Araştırmaları Dergisi, (34):1-23.

Belpınar, A. (2014). Gastronomi Turizmine Yönelik Turist Görüşlerinin Kültürlerarası Karşılaştırılması: Kapadokya Örneği. Yayınlanmamış Yüksek Lisans Tezi, Muğla Sıtkı Koçman Üniversitesi Sosyal Bilimler Enstitüsü, Muğla.

Bessiere, J. (1998). Local Development and Heritage: Traditional Food And Cuisine As Tourist Attractions in Rural Areas. Sociologia Ruralis, 38(1):21-34.

Biçici, F. (2008). Yiyecek İçecek İşletmelerinde Yabancı Turistlerin Psikolojik Fiyatlandırma Uygulamalarıyla İlgili Algzllamaları: Britanyalı Turistler Üzerinde Bir Çalışma. Yayınlanmamış Yüksek Lisans Tezi, Adnan Menderes Üniversitesi Sosyal Bilimler Enstitüsü, Aydın.

Birdir, K. ve Akgöl, Y. (2015). Gastronomi Turizmi ve Türkiye'yi Ziyaret Eden Yabancı Turistlerin Gastronomi Deneyimlerinin Değerlendirilmesi. İşletme ve İktisat Çalışmaları Dergisi, 3(2):57-68. 
Bucak, T. ve Ateş, U. (2014). Gastronomi Turizminin İl Turizmine Etkisi: Çanakkale Örneği. International Journal of Social Science, 2(28):315-328.

Bucak, T. ve Özkaya, E. (2015). Havalimanında Hizmet Veren Yiyecek-İçecek İşletmelerinde Fiyatın Misafir Memnuniyetine Etkisi (İstanbul Atatürk Havalimanı İç Hatlar Terminali Örneği). Gazi Üniversitesi Turizm Fakültesi Dergisi, (1):27-47.

Burucuoğlu, M. (2011). Müşteri Memnuniyeti ve Sadakatini Arttırmada Müşteri Şikâyetleri Yönetiminin Etkinliği: Bir Örnek Olay İncelemesi. Yayınlanmamış Yüksek Lisans Tezi, Karamanoğlu Mehmetbey Üniversitesi Sosyal Bilimler Enstitüsü, Karaman.

Cousins, J., Lillicrap, D. and Weekes, S. (2014). Food and Beverage Service. UK.

Çuhadar, M. (2006). Turizm Sektöründe Talep Tahmini İçin Yapay Sinir Ağları Kullanımı ve Diğgr Yöntemlerle Karşılaştırmalı Analizi (Antalya İlinin Dış Turizm Talebinde Uygulama). Yayınlanmamış Doktora Tezi. Süleyman Demirel Üniversitesi Sosyal Bilimler Enstitüsü, Isparta.

Duman, T. ve Öztürk, A. B. (2005). Yerli Turistlerin Mersin Kızkalesi Destinasyonu ve Tekrar Ziyaret Niyetleri İle İlgili Algılamaları Üzerine Bir Araştırma. Anatolia: Turizm Araştırmaları Dergisi, 16(1):9-23.

Duranoğlu, S., Yıldırım, İ. ve Koyuncu, İ. (2008). Antalya'daki Çeşitli Turistik İşletmelerinin Mutfaklarının Hijyen Yönünden Değerlendirilmesi. Türkiye 10. Gıda Kongresi, Erzurum.

Durgun, A. (2006). Bölgesel Kalkınmada Turizmin Rolü: Isparta Örneği. Yayınlanmamış Yüksek Lisans Tezi, Süleyman Demirel Üniversitesi, Sosyal Bilimler Enstitüsü, Isparta.

Emir, O. ve Avan, A. (2010). Yabancı Turistlerin Satın Alma Karar Sürecinde Kültürel Varlıkların Etkisi: Konya Örneği. Selçuk Üniversitesi Sosyal Bilimler Enstitüsü Dergisi, 204-219.

Erdem, O. ve Akkuş, G. (2013). Yemek Turizmine Katılma Niyeti: Planlı Davranış Teorisi Kapsaminda Bir Uygulama. K. Karamustafa (Editör) 14. Ulusal Turizm Kongresi Bildiriler Kitabı (s.636-654), Kayseri.

Giritlioğlu, İ. (2012). Yiyecek İçecek Bölümlerinde İşgörenlerin ve Müşterilerin Hizmet Kalitesi Beklenti ve Algıları: Termal Otellerde Bir Araştırma. Yayınlanmamış Doktora Tezi, Balıkesir Üniversitesi Sosyal Bilimler Enstitüsü, Balıkesir.

Görkem, Ö. (2015). Misafir Umduğunu mu Yer Bulduğunu mu? Otel İşletmelerinde Yiyecekİçecek Hizmetlerinin Değerlendirilmesi: Antalya Örneği. International Journal of Human Sciences, 12(1):315-326.

Güler, S. (2007). Yiyecek ve İçecek İşletmeleri İçin Rekabet Avantajı Yaratacak Stratejik Seçenekler. Anatolia: Turizm Araştırmaları Dergisi, 18(1):101-104.

Gülmez, Z. (2012). Türkiye'de ve Dünya'da Sağllk Turizmi ve Çeşitleri: Sağllk Turizminin Ülkemizdeki Mevcut Durumu ve Bazı Ülkelerle Kıyaslanması. Yayınlanmamış Yüksek Lisans Tezi, İstanbul Üniversitesi Sosyal Bilimler Enstitüsü, İstanbul.

Güneş, G., Ülker, H. İ. ve Karakoç, G. (2008). Sürdürülebilir Turizmde Yöresel Yemek Kültürünün Önemi. II. Ulusal Gastronomi Sempozyumu ve Sanatsal Etkinlikler, Antalya. 
Günlü, E. (2007). Turizm Sosyolojisi ve Turistik Tüketici Davranışlarl, Genel Turizm- Turizmde Temel Kavramlar ve Illkeler. Editör: O. İçöz, Ankara: Turhan Kitabevi.

Gürbüz, A. (2003). Safranbolu'ya Gelen Yerli Turistlerin Tatmin Olma Düzeyini Belirlemeye Yönelik Bir Araştırma. Gazi Üniversitesi Ticaret ve Turizm Ĕ̆itim Fakültesi Dergisi, (1):121.

Hatipoğlu, A. ve Batman, O. (2014). Turizm Eğitimiyle Kazanılacak Yetkinlikler, Yiyecekİçecek Müşterisinin Kalite Beklentilerini Karşıllyor Mu? Aksaray Üniversitesi İktisadi ve İdari Bilimler Fakültesi Dergisi, 6(2):24-32.

Hayta, A. B. (2008). Turizm Pazarlamasında Tüketici Satın Alma Süreci ve Karşılaşılan Sorunlar. Kastamonu Ĕ̆itim Dergisi, 16(1):31-48.

http://cthresource.com Erişim Tarihi: 11 Kasım, 2016.

http://www.connectedvivaki.com/dunyada-yemek-aliskanliklarinda-yeni-trendlerdoguyor/ Erişim Tarihi: 14 Ekim 2016.

https://www.tutorialspoint.com/food_and_beverage_services/food_and_beverage_services _tutorial.pdf Erişim Tarihi: 15 Kasım 2016.

Iskhakova, L. (2010). Sağ̆lklı Yaşam Tesislerinde (SPA) Müşteri Memnuniyeti: Antalya'daki 5 Yıldızlı Otel İşletmelerinde Bir Uygulama. Yayınlanmamış Yüksek Lisans Tezi, Akdeniz Üniversitesi Sosyal Bilimler Enstitüsü, Antalya.

İlban, M. O., Akkılıç, M. E. ve Yılmaz, Ö. (2011). Termal Turizmde Tüketici Satın Alma Davranışını Etkileyen Faktörlerin Belirlenmesi: Gönen Örneği. Marmara Üniversitesi S.B.E. Hakemli Dergisi, 9(36):39-51.

Jadhav, S. J. and Mor, V. S. (2010). Minimum Expectations of Tourists: An Essential Factor of Tourism Companies. International Journal of Trade, Economics and Finance, 1(2):184-188.

Kanca, B. (2012). Mersin Üniversitesi Merkez Kafeteryadaki Yiyecek İçecek Hizmetlerinin Üniversite Çalışanları ve Öğrencileri Tarafından Algılanan Kalite, Algılanan Değer, Memnuniyet ve Algılanan Risk Açısından Değerlendirilmesi. Yayınlanmamış Yüksek Lisans Tezi, Mersin Üniversitesi Sosyal Bilimler Enstitüsü, Mersin.

Kılıç, B. ve Babat, D. (2011). Kalite Fonksiyon Göçerimi: Yiyecek İçecek İşletmelerine Yönelik Kuramsal Bir Yaklaşım. MÜ Sosyal ve Ekonomik Araştırmalar Dergisi, 13(20):93-104.

Kızılırmak, İ. ve Kurtuldu, H. (2005). Kültürel Turizmin Önemi ve Tüketici Tercihlerinin Belirlenmesine Yönelik Bir Çalışma. Ticaret ve Turizm Eğitim Fakültesi Dergisi, (1):100120.

Koç, E. (2012). Tüketici Davranışı ve Pazarlama Stratejileri. İstanbul: Seçkin Yayıncılık.

Newsome, D. Moore, S. A. and Dowling, R. K. (2002). Natural Area Tourism: Ecology, Impacts and Management. Clevedon, GBR: Channel View Publications.

Okursoy, A. ve Turan, A. H. (2014). Açımlayıcı Faktör Analizi ve Üniversite Yemekhanesinde Müşteri Memnuniyeti Üzerinde Etkili Olan Boyutların Belirlenmesi Üzerine Bir Uygulama. Doğuş Üniversitesi Dergisi, 15(1):65-78.

Örgün, E., Solunoğlu, A. ve Yayla, Ö. (2013). Yiyecek İçecek İşletmelerinde Ziyaretçilerin Psikolojik Fiyatlandırmaya İlişkin Algıları: Ankara Örneği. Journal of Tourism and Gastronomy Studies 1(1):29-35. 
Özer, S. U. (2010). Şehir Turizmi ve Kültür: Yabancı Turistlerin Kültürel Bir Destinasyon Olarak İstanbul'u Değerlendirmeleri Üzerine Bir Araştırma. Yayınlanmamış Doktora Tezi, Anadolu Üniversitesi Sosyal Bilimler Enstitüsü, Eskişehir.

Öztürk, Y. ve Seyhan, K. (2005). Konaklama İşletmelerinde Sunulan Hizmet Kalitesinin SERVQUAL Yöntemi İle Ölçülmesi, Anotolia: Turizm Araştırma Dergisi, 16(2):172-182.

PSHE (2013). Introduction to Tourism (Fine-tuned version), Hong Kong: Tourism and Hospitality Studies.

Quan, S. and Wang, N. (2004). Towards A Structural Model of the Tourist Experience: An İllustration from Food Experiences in Tourism. Tourism Management, 25(3):297-305.

Sarışık, M. (2012). Yiyecek- İçecek Hizmetleri. Anadolu Üniversitesi (Açıöğretim/ Lisans), Eskişehir: 1 Baskı.

Seyitoğlu, F. ve Çalışkan, O. (2014). Turizm Literatüründe Türk Mutfağ Araştırmaların Değerlendirilmesi. Journal of Tourism and Gastronomy Studies, 2(4):2335.

Sezgin, E. K. (2010). Mutfak Personelinin Hizmet İçi Eğitiminin Örgütsel Bağlllık ve İş Tatminine Etkisi Üzerine Bir Uygulama. Yayınlanmamış Yüksek Lisans Tezi, Gazi Üniversitesi Eğitim Bilimleri Enstitüsü, Ankara.

Silberberg, T. (1995). Cultural Tourism and Business Opportunities for Museums and Heritage Sites. Tourism Management, 16(5):361-365.

Sormaz, Ü. (2015). İstanbul'da Yiyecek İçecek Sektöründe Hizmet Veren İşletmelerin Türk Mutfağ1 Uygulamaları. Journal of Tourism and Gastronomy Studies. 3(1):48-54.

Şanlıer, N. (2005). Yerli Ve Yabancı Turistlerin Türk Mutfağı Hakkındaki Görüşleri. Gazi Eğitim Fakültesi Dergisi, 1(25):213-227.

Ural, A. ve Kılıç, İ. (2006). Bilimsel Aştırma Süreci ve Spss İle Veri Analiz, Ankara: Detay Yayıncilik.

Yergaliyeva, A. (2011). Destinasyon Markalaşma Sürecinde Yerel Mutfağın Yeri (Uralsk Bölgesi'ndeki Restoranlar Üzerine Bir Araştırma). Yayınlanmamış Yüksek Lisans Tezi, Balıkesir Üniversitesi Sosyal Bilimler Enstitüsü, Balıkesir.

Zağralı, E. ve Akbaba, A. (2015). Turistlerin Destinasyon Seçiminde Yöresel Yemeklerin Rolü: İzmir Yarımadası'nı Ziyaret Eden Turistlerin Görüşleri Üzerine Bir Araştırma. Journal of Yaşar University, 10(40):6633-6644. 